\title{
Recent advances in diagnosis and treatment of chronic myeloproliferative neoplasms
}

\section{Paola Guglielmelli and Alessandro M Vannucchi*}

\author{
Address: Division of Hematology, Department of Critical Care, University of Florence, Viale G Morgagni 85, 50134 Firenze, Italy \\ *Corresponding author: Alessandro M Vannucchi (amvannucchi@unifi.it) \\ FI000 Medicine Reports 2010, 2:16 (doi:10.3410/M2-16)
}

The electronic version of this article is the complete one and can be found at: http://fl000.com/reports/medicine/content/2/16

\begin{abstract}
The Philadelphia chromosome-negative chronic myeloproliferative neoplasms (MPNs) have recently been the focus of tremendous advances in basic knowledge of disease pathophysiology following the recognition of mutations in JAK2 and MPL. These discoveries also led to refinement of the criteria employed for diagnosis. The prognostic roles of the JAK2 V6I7F mutation and of leukocytosis as independent risk factors for thrombosis, which represents the leading cause of death in patients with polycythemia vera and essential thrombocythemia, are supported by retrospective studies. A new risk stratification approach to the patient with primary myelofibrosis allows clinicians to distinguish categories of patients with significantly different expected survival. Finally, new drugs are currently being tested for MPNs, and molecular discoveries could ultimately lead to the development of a specific targeted therapy. Overall, significant advances in diagnosis, prognostication, and treatment have taken place in the last couple of years in the field of MPNs.
\end{abstract}

\section{Introduction and context}

The Philadelphia chromosome-negative chronic myeloproliferative neoplasms (MPNs) include polycythemia vera (PV), essential thrombocythemia (ET), and primary myelofibrosis (PMF) [1]. PV and ET are relatively indolent disorders that result in a modest reduction of survival, usually after the first decade from the time of diagnosis; PMF, on the other hand, has a more severe course and a median survival of about 5 years, although some patients experience survival of longer than 10 years. The course of PV and ET is marked by an excess of arterial and venous thrombosis, which represent the principal cause of morbidity and mortality; major hemorrhage, evolution to post-polycythemia vera/post-essential thrombocythemia myelofibrosis (PPV/PET-MF), and transformation to acute myeloid leukemia (AML) also contribute to reduced survival. Causes of death in patients with PMF are related to the consequences of myeloproliferation or bone marrow failure, vascular events, infections, and transformation to AML.
In 2005, a point mutation in exon 14 of the Janus kinase 2 gene (JAK2 V617F) was discovered in the majority of patients with PV and in about $60 \%$ of those with ET or PMF [2-5]. Additional mutations in exon 12 of JAK2 [6] and at codon 515 of the myeloproliferative leukemia virus oncogene (MPL) [7] were reported in a minority of patients with PV or in $5 \%$ and $10 \%$ of patients with ET and PMF, respectively. These mutant alleles all result in a gain of function due to constitutive activation of tyrosine kinase-dependent cellular signaling pathways, particularly the JAK-signal transducer and activator of transcription (JAK-STAT) pathway [8]. During the search for additional genetic abnormalities in MPNs with the use of high-resolution SNP (single-nucleotide polymorphism) analysis, a region of acquired UPD (uniparental disomy) was identified at chr4q24, where the TET2 gene maps [9]. Abnormalities in TET2 are believed to antedate the acquisition of JAK2 $\mathrm{V} 617 \mathrm{~F}$ point mutation in most, but not all, cases $[9,10]$. The precise function of TET2 is unknown, but the gene might behave as a bona fide oncosuppressor. However, it was soon shown that 
mutations in TET2 are found in only $10-15 \%$ of MPN patients and are shared by other myeloid malignances, in particular myelodysplastic syndromes and chronic myelomonocytic leukemia [11-14].

Clustering of myeloproliferative disorders in some families has been recognized for some time. Furthermore, a recent epidemiologic study from Sweden found that the risk of developing an MPN is up to seven-fold greater in first-degree relatives of MPN patients than in the general population [15]. The genetic predisposition to MPN, particularly but not exclusively among patients harboring the V617F mutation, has been attributed to a specific haplotype, called 46/1 or GGCC, that is located at chromosome 9 and includes the JAK2 gene itself [16-19].

Overall, this information has significantly advanced our understanding of the pathophysiology of MPN and, by pointing to mutated kinases as a common mechanism in these disorders, has suggested that tyrosine kinases might represent a valid target for therapy, as exemplified by the efficacy of imatinib and second-generation tyrosine kinase inhibitors in chronic myelogenous leukemia.

\section{Recent advances \\ Diagnosis}

One seminal advance has been the revision [20] of the criteria employed for diagnosis that was promoted by the demonstration of an almost universal association of the JAK2 V617F mutation with PV and an association in about $60 \%$ of patients with ET or PMF. According to the 2008 World Health Organization (WHO) classification [21], the presence of any of these mutations constitutes a major criterion for diagnosis. However, the diagnosis of ET or PMF still requires expert evaluation of bone marrow histopathology in order to identify specific morphologic patterns associated with either disease. Another clinical setting in which diagnosis has been significantly improved is represented by the splancnic vein thromboses that have been found to be associated with the JAK2 V617F mutation in up to half of cases [22], thus establishing an MPN as the commonest underlying cause [23]. Finally, a consensus statement from the International Working Group for Myelofibrosis Research and Treatment (IWGMRT) proposed uniform criteria for diagnosing the evolution of PV or ET to PPV/PET-MF [24]. Overall, these molecular and clinical advances have made the diagnostic work-up of the commonest MPN more effective and reproducible, a key premise for clinical studies and for the design of trials of innovative drugs.

\section{Prognosis}

The only criteria currently used for risk stratification of PV or ET patients are older age and previous history of thrombosis. However, several studies, supported by meta-analyses, have documented the association of the JAK2 V617F mutation with an increased risk of arterial and venous thrombosis in patients with ET (hazard ratio 1.8- to 2.0-fold greater than that of JAK2 unmutated ET patients) [25], particularly if the mutation is harbored in a homozygous status (i.e., both alleles are mutated) [26]. One study reported that patients with PV who have a high 'allele burden' (i.e., a prevalence of mutated versus normal alleles) are at greater risk for thrombosis [27]. It is also possible that the accumulation of mutated alleles in PV or ET accompanies transformation to PPV/PET-MF $[26,28]$. On the contrary, PMF patients with lower JAK2 V617F allele burden are at increased risk of death $[29,30]$. Thus, evidence that, in addition to diagnostic relevance, a JAK2 V617F mutated status or a high burden of mutated allele or both have prognostic correlates is being accumulated [31]. On the other hand, TET2 mutations have not been associated yet with clinical endpoints [32]. Finally, while it is accepted that the occurrence of thrombosis in PV or ET is not directly linked to raised hematocrit or platelet count, leukocytosis has recently been associated with increased risk of major vascular events and eventually could represent a major target of cytoreductive therapy [33].

Identification of PMF patients with expected shorter survival is pivotal for appropriate decision making in regard to hematopoietic stem cell transplantation, which offers the only chance of cure but is still burdened by significant mortality and morbidity. A new and highly discriminatory prognostic system has been devised by the IWG-MRT on the basis of a study of 1054 patients [34]. Variables predicting shortened survival were an age of greater than 65 years, presence of constitutional symptoms, hemoglobin level of less than $100 \mathrm{~g} / \mathrm{L}$, leukocyte count of greater than $25 \times 10^{9} / \mathrm{L}$, and percentage of circulating blast cells of $1 \%$ or greater. When these variables were used, four risk groups that differed significantly in median survival, ranging from 135 to 95,48 , and 27 months, were delineated [34]. These five variables maintained their impact on survival when analyzed as time-dependent covariates during the follow-up of PMF patients, whether younger or older than 65 years [35]. Therefore, prognostic assessment of patients with PMF can be performed anytime during their clinical course by using these criteria and may guide treatment decision.

\section{Treatment}

The central role that alterations in the JAK-STAT pathway play in clinical manifestations of MPN has made targeting JAK2 an appealing therapeutic goal $[36,37]$. A number of drugs exhibiting differential inhibitory 
activity against JAK family members and eventually on other receptor kinases, such as FGFR (fibroblast growth factor receptor), PDGFR (platelet-derived growth factor receptor), and FLT3 (FMS-like tyrosine kinase 3), are currently in clinical development. Most experience has been in patients with myelofibrosis in phase I/II trials employing INCB018424 (a potent and selective inhibitor of JAK1 and JAK2), TG101348 (a structure-based drug designed to inhibit JAK2 with great selectivity), CEP-701 (a multikinase inhibitor), and XL019 (a selective JAK2 inhibitor whose clinical development has been halted because of neurotoxicity). With some differences, the first results available indicated substantial activity against enlarged spleen and systemic symptoms, whereas the effects on the mutational burden were more variable [38].

While the use of JAK2 inhibitors is ongoing, other important trials have been completed in the last two years. Lenalidomide, an immunomodulating agent, was reported to produce a $20-30 \%$ response rate in anemia and splenomegaly, and overall this is similar to the experience with thalidomide and prednisone; myelotoxicity was common [39]. Another study indicated that the combination of lenalidomide and prednisone might be better tolerated, responses were more durable, and a significant reduction of JAK2 V617F allele burden was reported [40]. However, response rate and quality of response were impressive in myelofibrotic patients harboring the del(5)q abnormality, and lenalidomide should be considered as first-line therapy in this specific subset of patients [41]. A third thalidomide analog, pomalidomide, has been evaluated in a phase II randomized, multicenter, double-blind study. The drug was effective for treatment of anemia in up to $36 \%$ of the patients, with minimal hematological and extrahematological toxicity. No changes in JAK2 V617F allele burden were observed [42]. Similar results (33\% for hepatosplenomegaly and $38 \%$ for transfusiondependent anemia) were reported in a phase II trial with tipifarnib, a farnesyltransferase inhibitor [43].

The role of epigenetic abnormalities in the pathogenesis of MPNs represents a novel field of research [44]. In this regard, a recent paper reported that JAK2 possesses a nuclear activity and regulates the phosphorylation of histone H3 [45], thereby affecting the expression of target genes, including putative oncogenes such as Imo2. Furthermore, TET1, another member of the TET family, has been shown to catalyze the conversion of 5-methylcytosine to 5-hydroxymethylcytosine, possibly intervening in the regulation of transcriptional activity [46]. These observations may have therapeutic relevance. However, two similar but independent trials failed to observe any favorable effect of 5-azacytidine in myelofibrosis $[47,48]$. On the contrary, ITF2387, a histone deacethylase inhibitor, was reported to have significant activity in the control of hematological abnormalities and systemic symptoms in patients with PV or ET [49].

Interferon (IFN) has been used sporadically in PV and ET for some time. In France, a phase II study of pegylated IFN- $\alpha-2 \mathrm{a}$ in PV included 40 patients. Eighty-nine percent of the patients presented a mean decrease of the V617 allele of 44\%, with complete disappearance of the V617F allele in one patient. The results would confirm the hypothesis that IFN- $\alpha$ preferentially targets the malignant clone in PV [50].

The availability of novel drugs calls for the need to have standardized criteria for assessing response to therapy. While response criteria in patients with PMF were published several years ago [51,52], criteria of response to treatment in PV and ET patients have been published only recently following a European consensus conference [53].

\section{Implications for clinical practice}

Testing of the JAK2 V617F and, more selectively, MPL W515L/K/A or JAK2 exon 12 mutational statuses has made the diagnosis of MPN more precise than ever before. Therefore, genotyping for those mutations is mandatory in the work-up of a patient suspected of having an MPN. Nowadays, diagnoses are expected to strictly fulfill the 2008 WHO criteria. Also, the IWG-MRT criteria for the diagnosis of PPV/PET-MF should be routinely adopted in clinical practice. Genotype-phenotype associations have been identified; however, quantitative methods for measuring JAK2 V617F allele burden are specialized tools that are still best used within clinical trials. After all, the decision to treat ET or PV patients based on the presence of the mutation, a high mutated allele burden, or leukocytosis as surrogate markers of increased thrombotic risk deserves prospective validation and cannot be routinely recommended outside clinical trials.

It is now time to start assuming that the clinical course of MPNs may be improved by therapy and the disease possibly cured. Molecular discoveries have made the development of JAK2 tyrosine kinase inhibitors an attractive therapeutic goal, and molecules that inhibit JAK2 kinase are being evaluated with measurable results in the clinical setting. Actually, the rapid and marked improvement in splenomegaly and quality of life observed in myelofibrotic patients treated with INCB018424 or TG101348 has never been seen before with any drug and per se justify enthusiasm. Novel 
immunomodulatory agents may be better tolerated and more effective than thalidomide in the setting of myelofibrosis. Drugs acting on epigenetic gene regulation, either alone or eventually in combination, hold some promise. Finally, while it is noteworthy that IFN proved able to induce clonal remission in patients with PV, larger studies are needed to define the proportion of patients achieving such a goal as well as the long-term treatment tolerability of pegylated formulations. However, whether aiming at molecular remission is a valuable clinical endpoint for the long-term management of PV or ET, as it might be for myelofibrosis, still requires demonstration.

\section{Abbreviations}

$\mathrm{AML}$, acute myeloid leukemia; ET, essential thrombocythemia; IFN, interferon; IWG-MRT, International Working Group for Myelofibrosis Research and Treatment; JAK, Janus kinase; JAK-STAT, JAK-signal transducer and activator of transcription; MPL, myeloproliferative leukemia virus oncogene; MPN, myeloproliferative neoplasm; PMF, primary myelofibrosis; PPV/PET-MF, post-polycythemia vera/post-essential thrombocythemia myelofibrosis; PV, polycythemia vera; WHO, World Health Organization.

\section{Competing interests}

The authors declare that they have no competing interests.

\section{References}

I. Vannucchi AM, Guglielmelli P, Tefferi A: Advances in understanding and management of myeloproliferative neoplasms. CA Cancer J Clin 2009, 59:|7|-91.

2. Levine RL, Wadleigh M, Cools J, Ebert BL, Wernig G, Huntly BJ, Boggon TJ, Wlodarska I, Clark J], Moore S, Adelsperger J, Koo S, Lee JC, Gabriel S, Mercher T, D'Andrea A, Frohling S, Dohner K, Marynen P, Vandenberghe P, Mesa RA, Tefferi A, Griffin JD, Eck MJ, Sellers WR, Meyerson M, Golub TR, Lee SJ, Gilliland DG: Activating mutation in the tyrosine kinase JAK2 in polycythemia vera, essential thrombocythemia, and myeloid metaplasia with myelofibrosis. Cancer Cell 2005, 7:387-97.

3. James C, Ugo V, Le Couedic JP, Staerk J, Delhommeau F, Lacout C, Garcon L, Raslova H, Berger R, Bennaceur-Griscelli A, Villeval JL, Constantinescu SN, Casadevall N, Vainchenker W: A unique clonal JAK2 mutation leading to constitutive signalling causes polycythaemia vera. Nature 2005, 434: I 444-8.

FI000 Factor 6.0 Must Read

Evaluated by Hans Clevers 25 May 2005

4. Kralovics R, Passamonti F, Buser AS, Teo SS, Tiedt R, Passweg JR, Tichelli A, Cazzola M, Skoda RC: A gain-of-function mutation of JAK2 in myeloproliferative disorders. N Engl J Med 2005, 352: $1779-90$

5. Baxter EJ, Scott LM, Campbell PJ, East C, Fourouclas N, Swanton S, Vassiliou GS, Bench AJ, Boyd EM, Curtin N, Scott MA, Erber WN, Green AR: Acquired mutation of the tyrosine kinase JAK2 in human myeloproliferative disorders. Lancet 2005, 365:I054-6I.

6. Scott LM, Tong W, Levine RL, Scott MA, Beer PA, Stratton MR, Futreal PA, Erber WN, McMullin MF, Harrison CN, Warren AJ, Gilliland DG, Lodish HF, Green AR: JAK2 exon 12 mutations in polycythemia vera and idiopathic erythrocytosis. $N$ Engl J Med 2007, 356:459-68.

FI000 Factor 3.0 Recommended

Evaluated by Srdan Verstovsek 23 Mar 2007

7. Pikman $\mathrm{Y}$, Lee BH, Mercher T, McDowell E, Ebert BL, Gozo M, Cuker A, Wernig G, Moore S, Galinsky I, DeAngelo DJ, Clark J], Lee S), Golub TR, Wadleigh M, Gilliland DG, Levine RL: MPLW5 I5L is a novel somatic activating mutation in myelofibrosis with myeloid metaplasia. PLoS Med 2006, 3:e270.

FI000 Factor 3.0 Recommended

Evaluated by Srdan Verstovsek 07 Dec 2006

8. Levine RL, Pardanani A, Tefferi A, Gilliland DG: Role of JAK2 in the pathogenesis and therapy of myeloproliferative disorders. Nat Rev Cancer 2007, 7:673-83.

9. Delhommeau F, Dupont S, Della Valle V, James C, Trannoy S, Masse A, Kosmider O, Le Couedic JP, Robert F, Alberdi A, Lecluse Y, Plo I, Dreyfus FJ, Marzac C, Casadevall N, Lacombe C, Romana SP, Dessen P, Soulier J, Viguie F, Fontenay M, Vainchenker W, Bernard OA: Mutation in TET2 in myeloid cancers. $N$ Engl $J$ Med 2009, 360:2289-30I.

FI000 Factor 3.0 Recommended Evaluated by Richard Larson 25 Aug 2009

10. Saint-Martin C, Leroy G, Delhommeau F, Panelatti G, Dupont S, James C, Plo I, Bordessoule D, Chomienne C, Delannoy A, Devidas A, Gardembas-Pain M, Isnard F, Plumelle Y, Bernard O, Vainchenker W, Najman A, Bellanne-Chantelot C: Analysis of the ten-eleven translocation (TET)2 gene in familial myeloproliferative neoplasms. Blood 2009, I | 4:1628-32.

II. Abdel-Wahab O, Mullally A, Hedvat C, Garcia-Manero G, Patel J, Wadleigh M, Malinge S, Yao J, Kilpivaara O, Bhat R, Huberman $\mathrm{K}$, Thomas S, Dolgalev I, Heguy A, Paietta E, Le Beau MM, Beran M, Tallman MS, Ebert BL, Kantarjian HM, Stone RM, Gilliland DG, Crispino JD, Levine RL: Genetic characterization of TETI, TET2, and TET3 alterations in myeloid malignancies. Blood 2009, I I 4: 144-7.

12. Jankowska AM, Szpurka H, Tiu RV, Makishima H, Afable M, Huh J, O'Keefe CL, Ganetzky R, McDevitt MA, Maciejewski JP: Loss of heterozygosity 4q24 and TET2 mutations associated with myelodysplastic/myeloproliferative neoplasms. Blood 2009, | | 3:6403-10.

13. Langemeijer SM, Kuiper RP, Berends M, Knops R, Aslanyan MG, Massop M, Stevens-Linders E, van Hoogen P, van Kessel AG, Raymakers RA, Kamping EJ, Verhoef GE, Verburgh E, Hagemeijer A, Vandenberghe $P$, de Witte $T$, van der Reijden $B A$, Jansen $\mathrm{JH}$ : Acquired mutations in TET2 are common in myelodysplastic syndromes. Nat Genet 2009, 41:838-42.

FI000 Factor 3.0 Recommended

Evaluated by Effie Petersdorf 29 Jul 2009

14. Tefferi A, Lim KH, Abdel-Wahab O, Lasho TL, Patel J, Patnaik MM, Hanson CA, Pardanani A, Gilliland DG, Levine RL: Detection of mutant TET2 in myeloid malignancies other than myeloproliferative neoplasms: CMML, MDS, MDS/MPN and AML. Leukemia 2009, 23:1343-5.

15. Landgren O, Goldin LR, Kristinsson SY, Helgadottir EA, Samuelsson J, Bjorkholm M: Increased risks of polycythemia vera, essential thrombocythemia, and myelofibrosis among 24577 firstdegree relatives of II 039 patients with myeloproliferative neoplasms in Sweden. Blood 2008, I 1 2:2199-204.

FI000 Factor 3.0 Recommended Evaluated by Jason Gotlib 19 Jun 2008

16. Jones AV, Chase A, Silver RT, Oscier D, Zoi K, Wang YL, Cario H, Pahl HL, Collins A, Reiter A, Grand F, Cross NC: JAK2 haplotype is a major risk factor for the development of myeloproliferative neoplasms. Nat Genet 2009, 41:446-9.

FI000 Factor 6.4 Must Read

Evaluated by Monica Bessler 07 Apr 2009, Jason Gotlib 26 Jun 2009 
17. Olcaydu D, Harutyunyan A, Jager R, Berg T, Gisslinger B, Pabinger I, Gisslinger H, Kralovics R: A common JAK2 haplotype confers susceptibility to myeloproliferative neoplasms. Nat Genet 2009, 4I:450-4.

FI000 Factor 6.0 Must Read

Evaluated by Francesco Passamonti 31 Mar 2009

18. Olcaydu D, Skoda RC, Looser R, Li S, Cazzola M, Pietra D, Passamonti F, Lippert E, Carillo S, Girodon F, Vannucchi A, Reading NS, Prchal JT, Ay C, Pabinger I, Gisslinger H, Kralovics R: The 'GGCC' haplotype of JAK2 confers susceptibility to JAK2 exon 12 mutation-positive polycythemia vera. Leukemia 2009, 23:1924-6.

19. Kilpivaara O, Mukherjee S, Schram AM, Wadleigh M, Mullally A, Ebert BL, Bass A, Marubayashi S, Heguy A, Garcia-Manero G, Kantarjian H, Offit K, Stone RM, Gilliland DG, Klein RJ, Levine RL: A germline JAK2 SNP is associated with predisposition to the development of JAK2(V6I7F)-positive myeloproliferative neoplasms. Nat Genet 2009, 41:455-9.

FI000 Factor 6.0 Must Read

Evaluated by Sissy Jhiang II Aug 2009

20. Tefferi A, Thiele J, Orazi A, Kvasnicka HM, Barbui T, Hanson CA, Barosi G, Verstovsek S, Birgegard G, Mesa R, Reilly JT, Gisslinger H, Vannucchi AM, Cervantes F, Finazzi G, Hoffman R, Gilliland DG, Bloomfield CD, Vardiman JW: Proposals and rationale for revision of the World Health Organization diagnostic criteria for polycythemia vera, essential thrombocythemia, and primary myelofibrosis: recommendations from an ad hoc international expert panel. Blood 2007, I 10:1092-7.

Changes Clinical Practice

F1000 Factor 6.0 Must Read

Evaluated by Francesco Onida 28 Jun 2007

21. Swerdlow SH, Campo E, Harris NL, Jaffe ES, Pileri SA, Stein H, Thiele J, Vardiman JW(Eds): WHO Classification of Tumors of Haematopoietic and Lymphoid Tissues. Lyon, France: International Agency for Research on Cancer; 2008.

22. Dentali F, Squizzato A, Brivio L, Appio L, Campiotti L, Crowther M, Grandi AM, Ageno W: JAK2V617F mutation for the early diagnosis of $\mathrm{Ph}$ - myeloproliferative neoplasms in patients with venous thromboembolism: a meta-analysis. Blood 2009, I I3:5617-23.

23. Kiladjian JJ, Cervantes F, Leebeek FW, Marzac C, Cassinat B, Chevret S, Cazals-Hatem D, Plessier A, Garcia-Pagan JC, Murad SD, Raffa S, Janssen HL, Gardin C, Cereja S, Tonetti C, Giraudier S, Condat B, Casadevall N, Fenaux P, Valla DC: The impact of JAK2 and MPL mutations on diagnosis and prognosis of splanchnic vein thrombosis: a report on 24 I cases. Blood 2008, I I I:4922-9.

FI000 Factor 3.0 Recommended

Evaluated by Jason Gotlib 08 Jul 2008

24. Barosi G, Mesa RA, Thiele J, Cervantes F, Campbell PJ, Verstovsek S, Dupriez B, Levine RL, Passamonti F, Gotlib J, Reilly JT, Vannucchi AM, Hanson CA, Solberg LA, Orazi A, Tefferi A: Proposed criteria for the diagnosis of post-polycythemia vera and post-essential thrombocythemia myelofibrosis: a consensus statement from the international working group for myelofibrosis research and treatment. Leukemia 2008, 22:437-8.

25. Ziakas PD: Effect of JAK2 V6I7F on thrombotic risk in patients with essential thrombocythemia: measuring the uncertain. Haematologica 2008, 93:|4|2-4.

26. Vannucchi AM, Antonioli E, Guglielmelli P, Rambaldi A, Barosi G, Marchioli R, Marfisi RM, Finazzi G, Guerini V, Fabris F, Randi ML, De Stefano V, Caberlon S, Tafuri A, Ruggeri M, Specchia G, Liso V, Rossi E, Pogliani E, Gugliotta L, Bosi A, Barbui T: Clinical profile of homozygous JAK2V6I7F mutation in patients with polycythemia vera or essential thrombocythemia. Blood 2007, I 1 0:840-6.

27. Vannucchi AM, Antonioli E, Guglielmelli P, Longo G, Pancrazzi A, Ponziani V, Bogani C, Ferrini PR, Rambaldi A, Guerini V, Bosi A, Barbui T: Prospective identification of high-risk polycythemia vera patients based on JAK2(V6I7F) allele burden. Leukemia 2007, 21 : 1952-9.

28. Passamonti F, Rumi E, Pietra D, Della Porta MG, Boveri E, Pascutto $C$ Vanelli L, Arcaini L, Burcheri S, Malcovati L, Lazzarino M, Cazzola M: Relation between JAK2 (V6 I 7F) mutation status, granulocyte activation, and constitutive mobilization of CD34+ cells into peripheral blood in myeloproliferative disorders. Blood 2006, 107:3676-82.

29. Tefferi A, Lasho TL, Huang J, Finke C, Mesa RA, Li CY, Wu W, Hanson CA, Pardanani A: Low JAK2V6I7F allele burden in primary myelofibrosis, compared to either a higher allele burden or unmutated status, is associated with inferior overall and leukemia-free survival. Leukemia 2008, 22:756-6I.

30. Guglielmelli P, Barosi G, Specchia G, Rambaldi A, Lo Coco F, Antonioli E, Pieri L, Pancrazzi A, Ponziani V, Delaini F, Longo G, Ammatuna E, Liso V, Bosi A, Barbui T, Vannucchi AM: Identification of patients with poorer survival in primary myelofibrosis based on the burden of JAK2V6 I 7F mutated allele. Blood 2009, I I 4:1477-83

3I. Vannucchi AM, Antonioli E, Guglielmelli P, Pardanani A, Tefferi A: Clinical correlates of JAK2V6 I 7F presence or allele burden in myeloproliferative neoplasms: a critical reappraisal. Leukemia 2008, 22:1299-307.

32. Tefferi A, Pardanani A, Lim KH, Abdel-Wahab O, Lasho TL, Patel J, Gangat N, Finke CM, Schwager S, Mullally A, Li CY, Hanson CA, Mesa R, Bernard O, Delhommeau F, Vainchenker W, Gilliland DG, Levine RL: TET2 mutations and their clinical correlates in polycythemia vera, essential thrombocythemia and myelofibrosis. Leukemia 2009, 23:905-II.

33. Barbui T, Carobbio A, Rambaldi A, Finazzi G: Perspectives on thrombosis in essential thrombocythemia and polycythemia vera: is leukocytosis a causative factor? Blood 2009, I I 4:759-63.

34. Cervantes F, Dupriez B, Pereira A, Passamonti F, Reilly JT, Morra E, Vannucchi AM, Mesa RA, Demory JL, Barosi G, Rumi E, Tefferi A: New prognostic scoring system for primary myelofibrosis based on a study of the International Working Group for Myelofibrosis Research and Treatment. Blood 2009, I I 3:2895-90I.

35. Passamonti F, Cervantes F, Vannucchi AM, Morra E, Rumi E, Pereira A, Guglielmelli P, Pungolino E, Caramella M, Maffioli M, Pascutto C, Lazzarino M, Cazzola M, Tefferi A: A dynamic prognostic model to predict survival in primary myelofibrosis: a study by the IWG-MRT (International Working Group for Myeloproliferative Neoplasms Research and Treatment). Blood 2009, [Epub ahead of print].

36. Pardanani A: JAK2 inhibitor therapy in myeloproliferative disorders: rationale, preclinical studies and ongoing clinical trials. Leukemia 2008, 22:23-30.

37. Wernig G, Kharas MG, Okabe R, Moore SA, Leeman DS, Cullen DE, Gozo M, McDowell EP, Levine RL, Doukas J, Mak CC, Noronha G, Martin M, Ko YD, Lee BH, Soll RM, Tefferi A, Hood JD, Gilliland DG: Efficacy of TGI01348, a selective JAK2 inhibitor, in treatment of a murine model of JAK2V6I7F-induced polycythemia vera. Cancer Cell 2008, 13:3II-20.

38. Verstovsek S: Therapeutic potential of JAK2 inhibitors. Hematology Am Soc Hematol Educ Program 2009:636-42.

39. Tefferi A, Cortes J, Verstovsek S, Mesa RA, Thomas D, Lasho TL, Hogan WJ, Litzow MR, Allred JB, Jones D, Byrne C, Zeldis JB, Ketterling RP, McClure RF, Giles F, Kantarjian HM: Lenalidomide therapy in myelofibrosis with myeloid metaplasia. Blood 2006, 108: I 158-64.

40. Quintas-Cardama A, Kantarjian H, Manshouri T, Thomas D, Cortes J, Ravandi F, Garcia-Manero G, Ferrajoli A, Bueso-Ramos C, Verstovsek S: Lenalidomide plus prednisone results in durable clinical, histopathologic, and molecular responses in patients with myelofibrosis. J Clin Oncol 2009, 27:4760-6.

4I. Tefferi A, Lasho TL, Mesa RA, Pardanani A, Ketterling RP, Hanson CA: Lenalidomide therapy in $\operatorname{del}(5)(\mathrm{q} 3 \mathrm{I})$-associated myelofibrosis: cytogenetic and JAK2V6I7F molecular remissions. Leukemia 2007, 21:1827-8. 
42. Tefferi A, Verstovsek S, Barosi G, Passamonti F, Roboz G] Gisslinger $H$, Paquette RL, Cervantes F, Rivera CE, Deeg HJ, Thiele J, Kvasnicka HM, Vardiman JW, Zhang Y, Bekele BN, Mesa RA, Gale RP, Kantarjian HM: Pomalidomide is active in the treatment of anemia associated with myelofibrosis. J Clin Oncol 2009, 27:4563-9.

43. Mesa RA, Camoriano JK, Geyer SM, Wu W, Kaufmann SH, Rivera CE, Erlichman C, Wright J, Pardanani A, Lasho T, Finke C, Li CY, Tefferi A: A phase II trial of tipifarnib in myelofibrosis: primary, postpolycythemia vera and post-essential thrombocythemia. Leukemia 2007, 21:1964-70.

44. Vannucchi AM, Guglielmelli P, Rambaldi A, Bogani C, Barbui T: Epigenetic therapy in myeloproliferative neoplasms: evidence and perspectives. J Cell Mol Med 2009, 13:1437-50.

45. Dawson MA, Bannister AJ, Gottgens B, Foster SD, Bartke T, Green AR, Kouzarides T: JAK2 phosphorylates histone H3Y4I and excludes HPIalpha from chromatin. Nature 2009, 46I: 819-22.

FI000 Factor 6.5 Must Read

Evaluated by Andrew D Sharrocks 21 Oct 2009, Brent Cochran 27 Oct 2009, Warren Leonard 04 Jan 2010

46. Tahiliani M, Koh KP, Shen Y, Pastor WA, Bandukwala H, Brudno Y, Agarwal S, lyer LM, Liu DR, Aravind L, Rao A: Conversion of 5-methylcytosine to 5-hydroxymethylcytosine in mammalian DNA by MLL partner TETI. Science 2009, 324:930-5.

FI000 Factor 9.9 Exceptional

Evaluated by Stephan Beck 21 Apr 2009, Steven Henikoff 22 Apr 2009, Yi Eve Sun 23 Sep 2009, Christopher Schofield 30 Oct 2009

47. Mesa RA, Verstovsek S, Rivera C, Pardanani A, Hussein K, Lasho T, Wu W, Tefferi A: 5-Azacitidine has limited therapeutic activity in myelofibrosis. Leukemia 2008, 23:180-2.

48. Quintas-Cardama A, Tong W, Kantarjian H, Thomas D, Ravandi F, Kornblau S, Manshouri T, Cortes JE, Garcia-Manero G, Verstovsek S: A phase II study of 5-azacitidine for patients with primary and post-essential thrombocythemia/polycythemia vera myelofibrosis. Leukemia 2008, 22:965-70.

FI000 Factor 3.0 Recommended

Evaluated by Nikolaus Kroeger 30 Jul 2008

49. Rambaldi A, Dellacasa CM, Salmoiraghi S, Spinelli O, Ferrari ML, Gattoni E, Guglielmelli P, Vannucchi AM, Barosi G, Barbui T: A phase 2A study of the histone-deacetylase inhibitor ITF2357 in patients with Jak2V6I7F positive chronic myeloproliferative neoplasms. Blood (ASH Annual Meeting Abstracts) 2008, I I 2:100A.

50. Kiladjian JJ, Cassinat B, Chevret S, Turlure P, Cambier N, Roussel M, Bellucci S, Grandchamp B, Chomienne C, Fenaux P: Pegylated interferon-alfa-2a induces complete hematological and molecular responses with low toxicity in polycythemia vera. Blood 2008, II 2:3065-72.

5I. Tefferi A, Barosi G, Mesa RA, Cervantes F, Deeg HJ, Reilly JT, Verstovsek S, Dupriez B, Silver RT, Odenike O, Cortes J, Wadleigh M, Solberg LA Jr, Camoriano JK, Gisslinger $H$, Noel P, Thiele J, Vardiman JW, Hoffman R, Cross NC, Gilliland DG, Kantarjian H: International Working Group (IWG) consensus criteria for treatment response in myelofibrosis with myeloid metaplasia, for the IWG for Myelofibrosis Research and Treatment (IWG-MRT). Blood 2006, I08: 1497-503.

52. Barosi G, Bordessoule D, Briere J, Cervantes F, Demory JL, Dupriez B, Gisslinger H, Griesshammer M, Hasselbalch H, Kusec R, Le Bousse-Kerdiles MC, Liberato NL, Marchetti M, Reilly JT, Thiele J: Response criteria for myelofibrosis with myeloid metaplasia: results of an initiative of the European Myelofibrosis Network (EUMNET). Blood 2005, 106:2849-53.

53. Barosi G, Birgegard G, Finazzi G, Griesshammer M, Harrison C, Hasselbalch HC, Kiladjian JJ, Lengfelder E, McMullin MF, Passamonti F, Reilly JT, Vannucchi AM, Barbui T: Response criteria for essential thrombocythemia and polycythemia vera: result of a European LeukemiaNet consensus conference. Blood 2009, I 1 3:4829-33. 